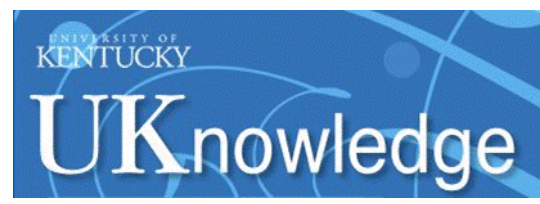

University of Kentucky

UKnowledge

\title{
Intramuscular Route of Administration Increases Potency in Eliciting Cocaine-Induced Behavioral Sensitization
}

\author{
Beth Ann Rice \\ University of Kentucky \\ Raza Tariq \\ University of Kentucky \\ Chana K. Akins \\ University of Kentucky, ckakin1@uky.edu
}

Follow this and additional works at: https://uknowledge.uky.edu/psychology_facpub

Part of the Psychology Commons, and the Substance Abuse and Addiction Commons

Right click to open a feedback form in a new tab to let us know how this document benefits you.

\section{Repository Citation}

Rice, Beth Ann; Tariq, Raza; and Akins, Chana K., "Intramuscular Route of Administration Increases Potency in Eliciting Cocaine-Induced Behavioral Sensitization" (2017). Psychology Faculty Publications. 164.

https://uknowledge.uky.edu/psychology_facpub/164

This Article is brought to you for free and open access by the Psychology at UKnowledge. It has been accepted for inclusion in Psychology Faculty Publications by an authorized administrator of UKnowledge. For more information, please contact UKnowledge@lsv.uky.edu. 


\section{Intramuscular Route of Administration Increases Potency in Eliciting Cocaine- Induced Behavioral Sensitization}

Digital Object Identifier (DOI)

https://doi.org/10.2174/2211556005666160902170354

Notes/Citation Information

Published in Current Psychopharmacology, v. 6, issue 1, p. 36-42.

(c) 2017 Bentham Science Publishers

The copyright holder has granted the permission for posting the article here.

The published manuscript is available at EurekaSelect via http://www.eurekaselect.com/openurl/ content.php?genre=article\&doi=10.2174/2211556005666160902170354.

This article is available at UKnowledge: https://uknowledge.uky.edu/psychology_facpub/164 


\title{
Intramuscular Route of Administration Increases Potency in Elic-
} iting Cocaine-Induced Behavioral Sensitization

\author{
Beth A. Rice, Raza Tariq and Chana K. Akins*
}

Department of Psychology, University of Kentucky, Lexington, KY 40506, USA

\begin{abstract}
Background: Cocaine is the number one abused psychostimulant drug that reaches addiction criterion in the US. In animals, repeated administration of cocaine results in behavioral sensitization which is thought to represent adaptations in the mesolimbic dopamine neural circuitry, the reward pathway. Cocaine-induced behavioral sensitization is evident in rodents and quail when cocaine is administered intraperitoneally (IP).
\end{abstract}

Objective: The purpose of the current study was to investigate dose-dependent and temporal effects of acute and chronic intramuscular (IM) administration of cocaine in male quail.

A R T I C L E H I S T O R Y

Received: June 21, 2016

Revised: August 24, 2016

Accepted: August 25, 2016

DOI:

DOI:
54
Method: After habituation to the test chambers, male quail received an IM injection of saline, 3 or $10 \mathrm{mg} / \mathrm{kg}$ cocaine and were immediately placed in the chambers. Distance traveled (in meters) was recorded in $5 \mathrm{~min}$ time bins for $30 \mathrm{~min}$. Testing was conducted once per day for ten days with each subject receiving the same treatment throughout the experiment. Other behaviors including pecking, preening, and feather fluffing were measured.

Results: Cocaine-induced behavioral sensitization and tolerance were evident at relatively low doses of IM cocaine. Dose-dependent effects were evident. IM cocaine also reduced feather fluffing, a behavior that typically occurs during hypothermia.

Conclusion: The findings replicated and extended previous research with pigeons and suggested that IM administration of cocaine may be a relatively potent route of administration. Potency of drugs of abuse may be related to the bioavailability of a drug and its addictive properties. Thus, studying drugs of abuse using an IM route of administration may be useful in drug addiction research.

Keywords: Intramuscular administration, locomotor activity, behavioral sensitization, tolerance, cocaine, male Japanese quail.

\section{INTRODUCTION}

Despite awareness of the harmful effects of cocaine taking, cocaine addiction persists. Cocaine is the number one abused psychostimulant drug that reaches addiction criterion in the US [1]. In animals, repeated administration of cocaine results in heightened motor stimulant effects, known as be-

*Address correspondence to this author at the 207Q Kastle Hall, Department of Psychology, University of Kentucky, Lexington, KY 40506-0044; Tel: (859) 257-1103; Fax: (859) 323-1979; E-mail: ckakin1@uky.edu havioral sensitization [2, 3]. Cocaine-induced sensitization is thought to represent adaptations in the mesolimbic dopamine neural circuitry, the pathway associated with reward [3]. These adaptations in the reward neural circuitry may later promote relapse [4].

In preclinical studies, the majority of cocaine sensitization studies utilize intraperitoneal (IP) injections as the primary route of administration in rodents [5-8] and quail [9-12]. Similar to rodent models, previous research in quail replicates the findings that IP administration of chronic cocaine 
dose-dependently enhances locomotor activity and induces cocaine sensitization $[10,11]$. Specifically, cocaine sensitization is evident with IP administration of cocaine ranging from doses of 10 to 23 $\mathrm{mg} / \mathrm{kg}$ in both rodents and quail using similar procedures [11, 13-15]. However, some studies show that IP injections of substances might have an estimated $23 \%$ miss rate and instead enter the kidney, small bowel, and intravascular system [16, 17].

There are differences in metabolism of drugs using IP versus IM routes of administration. IP administration undergoes the first-pass metabolism, which reduces the bioavailability of the drug [18]. However, IM injections avoid much of the first-pass metabolism, with 50-70\% lower doses than IP while providing a similar plasma concentration $[18,19]$. These differences in metabolism result in differences in cocaine's bioavailability $[20,21]$ which may, in turn, result in differences in potency of cocaine to induce sensitization.

IM administration of cocaine has been previously conducted in pigeons [22]. In this study, pigeons were given daily IM injections of 1,3 , and $10 \mathrm{mg} / \mathrm{kg}$ cocaine and locomotor activity, pecking, and preening were measured. A weighted-floor system was used in which locomotor activity was counted when the weight of a pigeon activated a switch on a particular floor section. All of the subjects received each dose in a within-subjects design. The results showed that all of the doses induced cocaine sensitization and cocaine dose-dependently decreased preening. Of particular interest, cocaine sensitization occurred at much lower doses ( 1 and $3 \mathrm{mg} / \mathrm{kg}$ ) in pigeons using the IM route of administration compared to rodents and quail given IP administration of cocaine [9-11, 23-27].

In human drug addiction, cues in the environment may become associated with drug taking and later, in the absence of the drug, cause craving and subsequent relapse. Therefore, an animal model that is more visually-oriented may be of additional relevance to human drug addiction. Although rodents are the most common species used in drug addiction research, they typically do not have good visual acuity and tend to rely on multimodal cues in their environment. Japanese quail have color vision and high visual acuity [28] that is similar to humans. Therefore, they may be ideal subjects to study drug addiction phenomena that involve visual environmental cues.
The purpose of the current study was to determine the effect of IM administration of cocaine on drug-induced locomotor activity in male Japanese quail. To extend previous work [22], locomotor activity was assessed as distance traveled and a between-subjects design was used to examine group effects. The studies also measured time bins to determine more specific effects of acute and chronic IM cocaine.

\section{METHODS}

\subsection{Subjects}

Twenty-four $(\mathrm{N}=24)$ adult male Japanese quail (Coturnix japonica) were supplied as eggs from Northwest Gamebirds (Kennewick, WA). Quail were hatched and raised in mixed sex groups until approximately four weeks of age, then housed in individual wire mesh cages (supplied by GQF Manufacturing, Savannah, GA). Male quail were randomly selected at 6-8 weeks old and maintained on a 19:8 hr light/dark cycle. Quail were maintained at $85 \%$ body mass, where food was available from 10 AM to 6 PM daily. This closely matches previously defined avian measures [2931].

All experimental procedures were conducted according to the guidelines of the Institutional Animal Care and Use Committee (IACUC) at the University of Kentucky and thereby in accordance with the standards set forth by the $8^{\text {th }}$ edition of the Guide for the Care and Use of Laboratory Animals.

\subsection{Drugs}

Cocaine hydrochloride (National Institute on Drug Abuse, Bethesda, MD) was dissolved in physiological saline $(0.9 \%)$ and injected intramuscularly (IM) at a volume of $1-\mathrm{ml} / \mathrm{kg}$ body weight. Doses of $3 \mathrm{mg} / \mathrm{kg}$ and $10 \mathrm{mg} / \mathrm{kg}$ and were chosen based on previous research that demonstrated cocaine-enhanced locomotor activity in pigeons with IM injections [22] and quail with IP injections [10, $11]$, respectively.

\subsection{Apparatus}

Distance traveled was used as an index of locomotor activity, and measured in 8 identical open field chambers. Each chamber had white plastic walls, screen mesh ceilings, and white corrugated paper the floor. The chambers measured $45.72 \mathrm{~cm}$ 
tall and $55.88 \mathrm{~cm}$ in diameter. Distance traveled was collected using ANY-Maze video tracking software (San Diego Instruments, San Diego, CA). All trials were recorded and later analyzed for behavioral measures including pecking, preening, and feather fluffing. Behavioral measures, except for feather fluffing, were chosen based on previous literature [22].

\subsection{Procedure}

Male quail were randomly assigned to receive 3 $\mathrm{mg} / \mathrm{kg}$ cocaine $(\mathrm{n}=8), 10 \mathrm{mg} / \mathrm{kg}$ cocaine $(\mathrm{n}=7)$, or saline $(n=8)$. Subjects were habituated to their assigned chamber for $30 \mathrm{~min}$ for two days before the start of the experiment. During testing, birds were weighed each day, injected IM with saline, 3 or $10 \mathrm{mg} / \mathrm{kg}$ cocaine and immediately placed in the chambers. Distance traveled (m) was recorded in $5 \mathrm{~min}$ time bins for $30 \mathrm{~min}$. Testing was conducted once per day for ten days with each subject receiving the same treatment throughout the experiment. All trials were videotaped. White noise was used throughout each phase of the experiment to attenuate extraneous noise.

\subsection{Statistical Analysis}

Cocaine-induced behavioral sensitization was assessed by comparing distance traveled on day 1 to day 10 [32]. A repeated-measures analysis of variance (ANOVA) was performed on the day (1 and 10) as a repeated measure and treatment (saline, 3 and $10 \mathrm{mg} / \mathrm{kg}$ cocaine) as the betweensubjects variable. To further probe a significant interaction, independent ANOVAs were conducted where appropriate.

Repeated-measures ANOVAs were also conducted across 5 min time bins separately for days 1 and 10 . For each day, time bin was the repeated measure and treatment (saline, 3 and $10 \mathrm{mg} / \mathrm{kg}$ cocaine) was the between-subjects variable. Independent ANOVAs and Fisher's LSD multiple comparisons served as posthoc analyses where appropriate.

Other behaviors including preening, pecking, and feather fluffing were analyzed similarly as distance traveled on days 1 and 10. Duration of preening was measured when birds cleaned or straightened their feathers with their beaks. The frequency of pecks made to the floor and walls was measured. Preening and pecking were chosen based on previous research [22]. The frequency of feather fluffing, which was signified by a bird puffing out their feathers was also measured because several instances of it were observed early in the experiment. All data were analyzed using SPSS software version 22 (International Business Machines Corp. (IBM), Armonk, NY). A Grubb's test was utilized in each treatment group before analyses to remove outliers. One outlier from the $10 \mathrm{mg} / \mathrm{kg}$ group was removed from the final dataset using this method. The final sample size for the current experiment was 23 . The level of statistical significance was chosen as $\mathrm{p}<0.05$.

\section{RESULTS}

Fig. (1) represents the mean distance traveled for subjects that received saline, 3 or $10 \mathrm{mg} / \mathrm{kg} \mathrm{IM}$ injections on Day 1 and 10. A repeated-measures ANOVA revealed a significant Treatment $\mathrm{x}$ Day interaction, $F(2,20)=4.2$. Independent repeatedmeasures ANOVAs showed that subjects that received $3 \mathrm{mg} / \mathrm{kg}$ cocaine had significantly greater distance traveled on Day $10(\mathrm{M}=13.91$, SEM 2.44) compared to Day $1(\mathrm{M}=6.20, \mathrm{SEM}=1.27), \mathrm{F}(1,7)$ $=8.42$. Neither saline nor the $10 \mathrm{mg} / \mathrm{kg}$ cocaine treatment resulted in increased distance traveled from Day 1 to Day 10, F's ranged from 0.03-0.7.

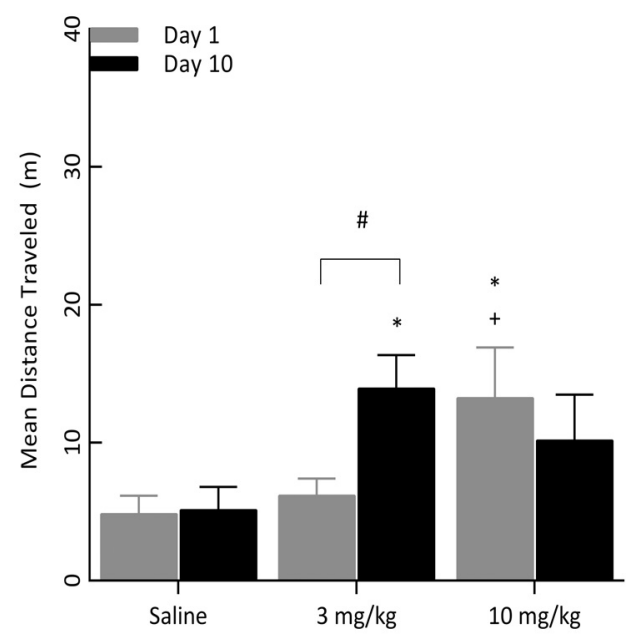

Fig. (1). Mean distance traveled (m) + SEM on Day 1 and Day 10 for saline, 3 and $10 \mathrm{mg} / \mathrm{kg}$ cocaine. * indicates significant difference for saline, + indicates significant difference from $3 \mathrm{mg} / \mathrm{kg}$ cocaine, and \# indicates significant difference of Day 1 vs. Day 10, $p<0.05$.

A separate one-way ANOVA on Day 1 indicated that subjects treated with $10 \mathrm{mg} / \mathrm{kg}$ cocaine had greater distance traveled compared to subjects treated with $3 \mathrm{mg} / \mathrm{kg}$ cocaine and saline, F $(2,22)$ $=3.9$. On Day 10, no treatment groups differed in distance traveled, $\mathrm{F}=3.3$. 
Fig. 2 represents the mean distance traveled in 5 min Time bins for subjects treated with saline, 3, or $10 \mathrm{mg} / \mathrm{kg}$ cocaine on Day 1 (Fig. 2A) and Day 10 (Fig. 2B). A repeated-measures ANOVA indicated that on Day 1 there was a significant Time bin $\mathrm{x}$ Treatment interaction, F (10, 100), 2.49, $\mathrm{p}<$ 0.05 . Independent one-way ANOVAs revealed treatment differences in distance traveled for Time bins 4, 5, and 6, F's ranged from 5.2 to 5.7. Significant main effects of Treatment $(F(2,20)=3.9)$ and Time bin $(F=2,20)=9.4$ were also evident on Day 1.

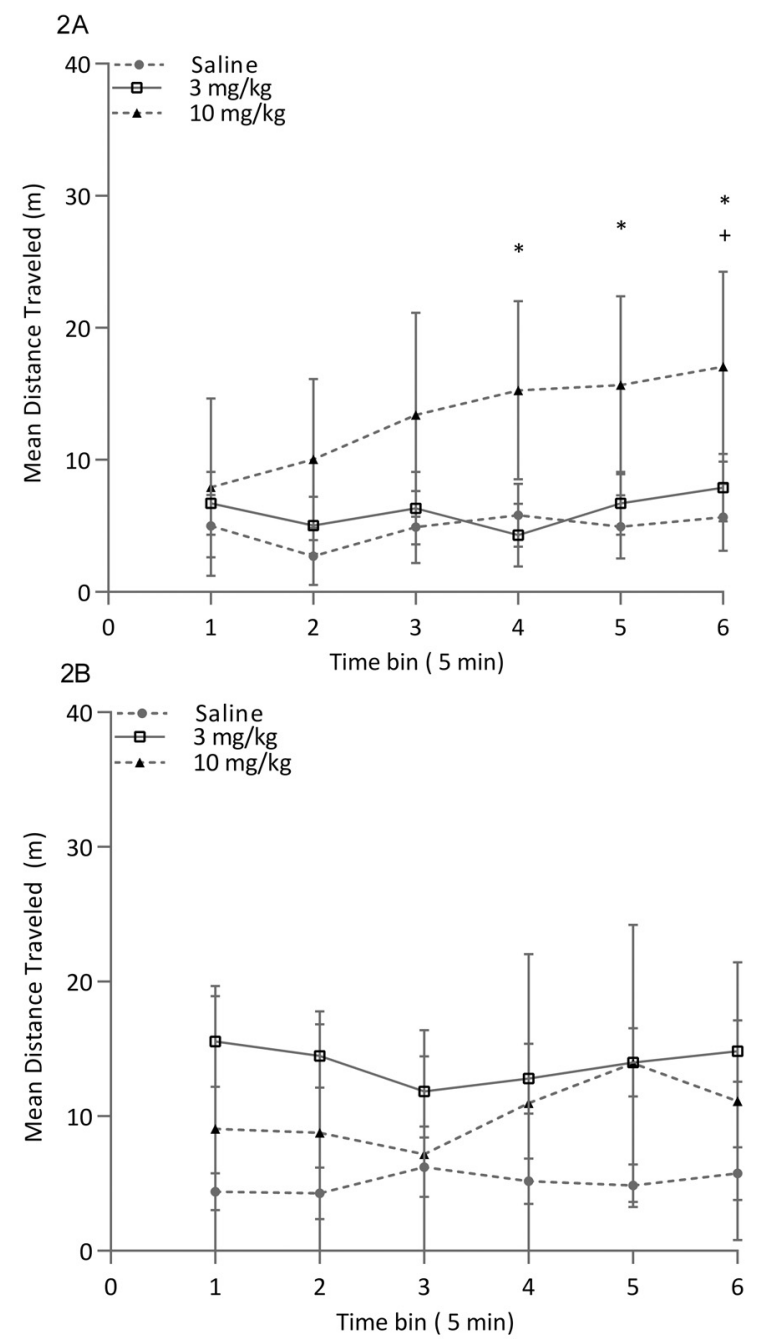

Fig. (2). Mean distance traveled across 6, 5 min time bins for saline, 3 and $10 \mathrm{mg} / \mathrm{kg}$ cocaine of Day 1 (2A) and day 10 (2B). Error bars are \pm SEM. * indicates 10 $\mathrm{mg} / \mathrm{kg}$ cocaine group significantly different from saline and $3 \mathrm{mg} / \mathrm{kg}$ cocaine, + indicates $10 \mathrm{mg} / \mathrm{kg}$ cocaine group significantly different from time bin 1 to time bin 6 .

Further analysis showed that subjects that received $10 \mathrm{mg} / \mathrm{kg}$ cocaine had significantly greater distance traveled on Time bin $6(\mathrm{M}=17.06$, $\mathrm{SEM}=4.35)$ compared to Time bin $1(\mathrm{M}=7.94$, $\mathrm{SEM}=3.51), \mathrm{F}(1,6)=10.24$. For Day 10 (Fig. 2B), a repeated measures ANOVA failed to reveal a significant Treatment $\mathrm{x}$ Time bin interaction, $\mathrm{F}$ $(10,100)=1.44$.

Administration of IM cocaine on other behaviors was investigated with a repeated-measures ANOVA with Day as a repeated measure (1 and 10) and Treatment as a between-subjects factor. There were no significant Treatment x Day interactions for frequency of pecking or duration of preening, where F's were 0.51 to 0.45 , respectively. There were also no significant main effects of treatment for pecking or preening, as F's were 2.8 and 0.21 , respectively.

A repeated measures ANOVA for the frequency of feather fluffing revealed a near significant Treatment $x$ Day interaction, $F(2,19)=6.78, p=$ 0.52 , and a main effect of Treatment, $F(2,19)=$ 8.32. Fisher's LSD post hoc analysis indicated that birds that received saline $(\mathrm{M}=2.69, \mathrm{SEM}=0.25)$ had a higher frequency of feather fluffs compared to birds that received $3 \mathrm{mg} / \mathrm{kg}$ cocaine $(\mathrm{M}=1.29$, $\mathrm{SEM}=0.25)$ and $10 \mathrm{mg} / \mathrm{kg}$ cocaine $(\mathrm{M}=1.64$, $\mathrm{SEM}=0.26$ ).

\section{DISCUSSION}

Results showed that cocaine-induced behavioral sensitization occurred when birds were given IM administration of $3 \mathrm{mg} / \mathrm{kg}$ cocaine. These subjects had a cocaine-induced increase in locomotor activity from day 1 to day 10 . While sensitization was not evident for birds given IM administration of 10 $\mathrm{mg} / \mathrm{kg}$, those birds showed the greatest locomotor activity on day 1 and this activity appeared to decrease by day 10. Cocaine did not appear to have any significant effects on duration of preening or frequency of pecking. However, the frequency of feather fluffing decreased from day 1 to day 10 for both cocaine doses relative to saline.

The current findings are consistent with previous research investigating the effects of IM cocaine administration in pigeons and they further validate the use of the apparatus developed by Pinkston and Branch [22] to measure drug-induced locomotor activity effects in birds. Pinkston and Branch [22] observed a cocaine-induced increase 
in locomotor activity in pigeons that received IM administration of 1,3 , and $10 \mathrm{mg} / \mathrm{kg}$ cocaine. Previous studies on IP administration of cocaine have been conducted in Japanese quail. These studies reported behavioral sensitization and increased locomotor activity when quail were given IP injections of 10 and $23 \mathrm{mg} / \mathrm{kg}$ cocaine but not $5 \mathrm{mg} / \mathrm{kg}$ $[10,12]$. The current findings on IM administration and Pinkston and Branch's work with pigeons [22] suggest that IM injections of cocaine may be relatively more potent than IP injections and thereby induce cocaine sensitization and tolerance at lower doses and more acutely.

The current findings for IM administration of 10 $\mathrm{mg} / \mathrm{kg}$ cocaine were unique to the previous literature with pigeons [22]. Rather than demonstrating cocaine-induced behavioral sensitization, this treatment induced a high level of locomotor activity acutely that appeared to decrease with chronic administration. This is perhaps an indication of behavioral tolerance. In rodents, behavioral tolerance is induced with relatively high doses of IP cocaine (e.g., $40 \mathrm{mg} / \mathrm{kg}$ ) or continuous long-term exposure to IP cocaine [32]. The current findings indicate that tolerance may have been evident with a relatively low dose of IM cocaine and shorter exposure. This provides additional evidence for increased potency of cocaine with the IM route of administration.

Differences in potency of IM and IP cocaine administration may be due to differences in metabolism. IP administration undergoes the firstpass metabolism, which reduces the bioavailability of the drug [21]. However, IM injections avoid much of the first-pass metabolism, with $50-70 \%$ lower doses than IP while providing a similar plasma concentration $[19,21]$. Thus, the bioavailability of cocaine depends on the route of administration $[21,33]$.

Typically, in both rodents and quail, cocaine sensitization is measured during $30 \mathrm{~min}$ locomotor activity sessions with IP injections of cocaine [11, 14, 15]. Pinkston \& Branch [22] gave $150 \mathrm{~min}$ cocaine locomotor activity sessions. This difference in session length and other methodological differences might explain some of the differences between the present study and their study. However, previous cocaine IP studies conducted in our laboratory utilized the same session length and dose of cocaine as in the current experiment $[11,12]$.
The only difference was the route of administration (IP versus IM). Those studies reported cocaine sensitization with IP injections rather than what appears to be tolerance with IM injections in the current experiment. Therefore, session length did not appear to play a role in the acquisition of tolerance in the current experiment.

Similar to the findings of Pinkston and Branch [22], surprisingly IM cocaine did not appear to affect pecking behavior. This is in contrast to the previous finding that the direct dopamine agonist apomorphine elicits drug-induced pecking in pigeons [34]. Furthermore, Pinkston and Branch [22] observed a dose-dependent decrease in preening behavior in pigeons that received IM cocaine. The current study did not find an effect of IM cocaine on preening behavior but it did find that IM cocaine decreased feather fluffing compared to IM saline. Typically, feather fluffing occurs during hypothermia and occurs with shivering [35]. Cocaine has been shown to increase core body temperatures of rodents [33]. Therefore, although speculative, it may be that in the current study, IM administration of cocaine increased the core body temperature of the birds and this resulted in a decrease in the occurrence of feather fluffing.

\section{CONCLUSION}

In summary, the present study suggests that IM cocaine administration may be a relatively potent route of administration that should be considered for future substance abuse research in some species. Because the route of administration of cocaine plays a role in the pharmacokinetics of cocaine and its addictive properties, the IM route of administration may be of additional benefit for studying drug addiction research. It should be noted that the methods for assessing behavioral sensitization in rodents and quail are comparable for the most part.

\section{ETHICAL STATEMENT}

This work reported experiments in accordance with the standards set forth in the $8^{\text {th }}$ Edition of Guide for the Care and Use of Laboratory Animals (http:/grants.nih.gov/grants/olaw/Guide-for-thecareand-use-oflaboratory-animals.pdf) published by the National Academy of Sciences, The National Academies Press, Washington DC, United States of America. 


\section{CONFLICT OF INTEREST}

The authors (Rice, Tariq, \& Akins) declare no conflict of interest and all of the authors contributed substantially to this article.

\section{ACKNOWLEDGEMENTS}

This research was supported by the National Institutes of Health under the Ruth L. Kirschstein Research Service Award (T32 DA035200) awarded to BAR. The funding agencies had no role in the study design, data collection, analysis, preparation or submission of the manuscript.

\section{REFERENCES}

[1] Substance abuse and mental health services administration (SAMHSA): Results from the 2012 national survey on drug use and health: Summary of national findings. Rockville MD. Substance abuse and mental health services administration, 2013. [Cited 2016 Feb 2] NSDUH Series H46, HHS Publication No.(SMA) 13-4795. Available from: URL:http://www.samhsa.gov/data/sites/default/files/NSDU $\mathrm{H}$ results2012/NSDUHresults2012.pdf

[2] Robinson TE, Becker JB. Enduring changes in brain and behavior produced by chronic amphetamine administration: a review and evaluation of animal models of amphetamine psychosis. Brain Res 1986; 396(2): 157-98.

[3] Kalivas PW, Stewart J. Dopamine transmission in the initiation and expression of drug and stress-induced sensitization of motor activity. Brain Res 1991; 16(3): 223-44.

[4] Steketee JD, Kalivas PW. Drug wanting: behavioral sensitization and relapse to drug-seeking behavior. Pharmacol Rev 2011; 63(2): 348365.

[5] Carey R, Gui J. Cocaine sensitization can accelerate the onset of peak cocaine behaviroal effects. Pharmacol Biochem Behav 1988; 60(2): 395405.

[6] Eisener-Dorman AF, Grabowski-Boase L, Tarantino LM. Cocaine locomotor activation, sensitization and place preference in six inbred strains of mice. Behav Brain Funct 2011; 7: 29.

[7] Flagel SB, Watson SJ, Akil H, Robinson TE. Individual differences in the attribution of incentive salience to a reward-related cue: influence on cocaine sensitization. Behav Brain Res 2008 186(1): 48-56.

[8] Post RM. Intermittent versus continuous stimulation: effect of time interval on the development of sensitization or tolerance. Life Sci 1980; 26(16): 1275-82.

[9] Akins CK, Geary EH. Cocaine-induced behavioral sensitization and conditioning in male Japanese quail. Pharmacol Biochem Behav 2008; 88(4): 432-7.

[10] Geary EH, Akins CK. Cocaine sensitization in male quail: temporal, conditioning, and dose-dependent characteristics. Physiol Behav 2007; 90(5): 818-24.

[11] Gill KE, Madison FN, Akins CK. Cocaine-induced sensitization correlates with testosterone in male Japanese quail but not with estradiol in female Japanese quail. Horm Behav 2015; 67: 21-7.

[12] Levens N, Akins CK. Chronic cocaine pretreatment facilitates Pavlovian sexual conditioning in male Japanese quail. Pharmacol Biochem Behav 2004; 79(3): 451-7.

[13] Yeh SY, Haertzen CA. Cocaine-induced locomotor activity in rats. Pharmacol Biochem Behav 1991; 39(3): 723-27.
[14] Galeano P, Romero JI, Luque-Rojas MJ, et al. Moderate and severe perinatal asphyxia induces differential effects on cocaine sensitization in adult rats. Synapse 2013; 67(9): 553-67.

[15] Blanco E, Galeano P, Palomino A, et al. Cocaine-induced behavioral sensitization decreases the expression of endocannabinoid signaling-related proteins in the mouse hippocampus. Eur Neuropsychopharmacol 2015; 26(3): 477-92.

Das RG, North D. Implications of experimental technique for analysis and interpretation of data from animal experiments: outliers and increased variability resulting from failure of intraperitoneal injection procedures. Lab Ani 2007; 41(3): 312320

[17] Steward JP, Ornellas EP, Beernink KD, Northway WH. Errors in the technique of intraperitoneal injection of mice. Appl Microbiol 1968; 16(9): 1418-9.

[18] Hedenqvist P, Hellebrekers LJ. Laboratory animal analgesia, anesthesia, and euthanasia. In: Jann H, Schapiro SJ. Handbook of Laboratory Animal Science. Volume 1: Essential Principles and Practices. $2^{\text {nd }}$ ed. Boca Raton, Florida: CRC Press LLC 2003; pp. 413-56.

[19] Brunton LL, Parker KL, Buxton ILO, Blumenthal DK. Drug Metabolism. Goodman \& Gilman's The Pharmacological Basis of Therapeutics. $11^{\text {th }}$ ed. New York: McGrawHill. Inc. 2007.

[20] Fattinger K, Benowitz NL, Jones RT, Verotta D. Nasal mucosal versus gastrointestinal absorption of nasally administered cocaine. Eur J Clin Pharmacol 2000; 56(4): $305-$ 10.

[21] Barnett G, Hawks R, Resnick R. Cocaine pharmacokinetics in humans. J Ethnopharmacol 1981; 3(2-3): 353-66.

[22] Pinkston JW, Branch MN. Acute and chronic effects of cocaine on the spontaneous behavior of pigeons. J Exp Anal Behav 2010; 94(1): 25-36.

[23] Chin J, Sternin O, Wu HB, et al. Endogenous gonadal hormones modulate behavioral and neurochemical responses to acute and chronic cocaine administration. Brain Res 2002; 945(1): 123-30.

[24] Erb S, Funk D, Le AD. Prior, repeated exposure to cocaine potentiates locomotor responsivity to central injections of corticotropin-releasing factor $(\mathrm{CRF})$ in rats. Psychopharmacol 2003; 170(4): 383-9.

[25] Lepsch LB, Gonzalo LA, Magro FJ, Delucia R, Scavone C, Planeta CS. Exposure to chronic stress increases the locomotor response to cocaine and the basal levels of corticosterone in adolescent rats. Addict Biol 2005; 10(3): 2516.

[26] Araujo AP, DeLucia R, Scavone C, Planeta CS. Repeated predictable or unpredictable stress: effects on cocaineinduced locomotion and cyclic AMP-dependent protein kinase activity. Behav Brain Res 2003; 139(1-2): 75-81.

[27] Kozanian OO, Gutierrez A, Mohd-Yusof A, McDougall SA. Ontogeny of methamphetamine-induced and cocaineinduced one-trial behavioral sensitization in preweanling and adolescent rats. Behav Pharmacol 2012; 23(4): 367-79.

[28] Fidura FG, Gray JA. Visual discrimination of color, pattern, and form in the japanese quail coturnix japonica. Psychono Sci 1966; 5(11): 427-8.

[29] Duval C, Cassey P, Lovell PG, Miksik I, Reynolds SJ, Spencer KA. Eggshell appearance does not signal maternal corticosterone exposure in Japanese quail: an experimental study with brown-spotted eggs. PLoS One 2013; 8(12): e80485.

[30] Duval C, Cassey P, Miksik I, Reynolds SJ, Spencer KA. Condition-dependent strategies of eggshell pigmentation: an experimental study of Japanese quail (Coturnix coturnix japonica). J Exp Biol 2013; 216(4): 700-8.

[31] Shousha S, Nakahara K, Nasu T, Sakamoto T, Murakami N. Effect of glucagon-like peptide-1 and -2 on regulation of 
food intake, body temperature and locomotor activity in the Japanese quail. Neurosci Lett 2007; 415(2): 102-7.

[32] King GR, Hillburn C, Pinto G, Konen J. The effects of continuous cocaine dose, treatment, and withdrawal duration on the induction of behavioral tolerance and dopamine autoreceptor function. Pharm Biochem Beh 2004; 78(2): 293-300.

[33] Jaehne EJ, Salem A, Irvine RJ. Pharmacological and behavioral determinants of cocaine, methamphetamine, 3,4 methylenedioxymethamphetamine, and para-methoxy- amphetamine- induced hyperthermia. Psychopharmacology 2007; 194(1): 41-52.

[34] Abelson JS, Woods JH. Effects of apomorphine on elicited and operant pecking in pigeons. Psychopharm 1980; 71: 237-41.

[35] Mills AD, Crawford LL, Domjan M, Faure JM. The behavior of the Japanese or domesticated quail Coturnix japonica. Neurosci Biobeh Rev 1997, 21(3): 261-81. 